平成 10 年度助成研究報告

\title{
ロシア卓状地における上部石炭系の有孔虫・ コノドント複合生層序（予報）
}

\author{
上 野 勝 美* 水 野 嘉 宏** NEMIROVSKAYA, Tamara I. *** \\ ALEKSEEV, Alexander S.****
}
Upper Carboniferous Foraminiferal and Conodont Biostratigraphy of the Russian Platform (Preliminary Report)

Katsumi UENO* ${ }^{*}$ Yoshihiro MIZUNO**, Tamara I. NEMIROVSKAYA*** and Alexander S. ALEKSEEV****

I. はじめに

ヨーロッパ東部に位置し, 東をウラル山脈によっ て境されたロシア卓状地（Russian Platform） には, 水河性の輪廻堆積相を示す浅海性石炭系が 非常に良く発達しており, 豊富な動植物化石群集 を含むことが知られている（例えば, Wagner and Higgins, 1979)。その中でもモスクワ盆地周辺 (ロシア連邦) とドネッ炭田（ウクライナ）地域 は，堆積物の連続性および産出する化石の豊富さ により，それぞれ石炭系標準層序における模式セ クションおよび重要なリファレンスセクションの ひとつとなっている。

両地域の石炭系層序に関しては，これまでの多 くの研究成果により比較的詳しくなっているもの の（例えば, Einor, 1996), 年代層序を考える上 で重要な生層序の基礎デー夕に関しては, MidCarboniferous 境界などの一部の層準を除いては いまだ 1950～80 年代前半までのものがほとんど
である。今日，西ヨーロッパや北米中央部の石炭 系において非常に精度の高い生層序の再検討が行 なわれ, 解像度の高い生層序分帯が確立している 中で，現在その見直しが必要となってきている。 また，これら生層序研究の中核をなすフズリナ． コノドント類の分類学的な研究も, 近年大きな進 歩を遂げており，既存のデータに関しても新しい 視点による分類学的な見直しが求められている。

本研究の目的は, ロシア・モスクワ盆地とウク ライナ・ルガンスク近郊のドネツ炭田地域（図 1) における Moscovian から Gzhelianにかけての上 部石炭系有孔虫・コノドント生層序について, 高 いサンプリング精度での再検討を行ない, 対比解 像度の高い, 新しい生層序分帯の枠組みを確立す ることにある。特に, モスクワ盆地周辺は上部石 炭系の3つの統である Moscovian, Kasimovian, Gzhelianの模式地を含んでいることから，国際石 炭系層序委員会に現在設立されている層序境界問 題検討のためのワーキンググループ（SCCS

* 福岡大学理学部地球圈科学教室

** 千葉大学理学部地球科学教室

*** ウクライナ科学アカデミー地質科学研究所

**** モスクワ大学地質学部古生物学教室

* Department of Earth System Science, Faculty of Science, Fukuoka University

* * Department of Earth Sciences, Faculty of Science, Chiba University

*** Institute of Geological Sciences, Ukrainian Academy of Sciences

**** Department of Paleontology, Faculty of Geology, Moscow State University 


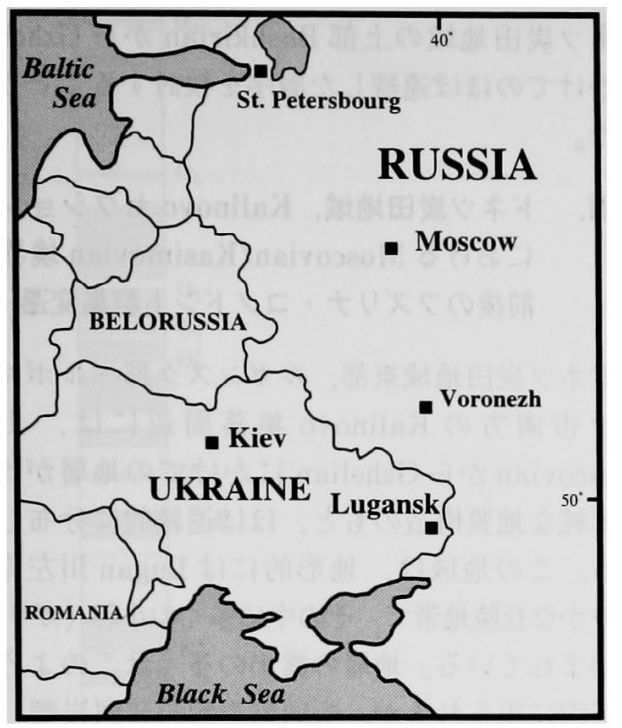

図 1 ロシア・モスクワ盆地とウクライナ・ルガン スクの位置図.

Fig. 1 Index map of the Moscow Basin in Russia and Lugansk of the Donets Basin in Ukraine.

Working Group to define a GSSP close to the Moscovian/Kasimovian boundary) の主要研究 対象地域のひとつでもあり，筆者らもそのメンバー となり共同研究を進めている。

本研究では Moscovian/Kasimovian 境界およ びKasimovian/Gzhelian 境界を挟んでの有孔虫 · コノドント群集変遷とその生層序境界問題, なら びに境界模式地策定のためのマーカーとなる生層 序時間面の検討を中心に研究を行なった。

現在, 得られたサンプルの処理を順次進めてい るが, ここでは今回の調査の概要について報告す るとともにこれまでに明らかになったドネッ炭 田地域の Kalinovo セクションにおける上部 Moscovian から下部 Kasimovian にかけてのフズ リナ・コノドント群集変遷の概要と, Moscovian/ Kasimovian 境界について報告する。

本研究を進めるにあたり，ドイッ・エルランゲ ン大学古生物学教室の Elias Samankassou 博士 および Beate Fohrer 博士には，ドネッ炭田地域 の野外調査の際に御同行いただくとともに，有益
な御助言をいただいた。また，スペイン・オビエ ド大学理学部地質学教室の Elisa Villa 教授をは じめとする国際石炭系層序委員会 Moscovian/ Kasimovian 境界策定のためのワーキンググルー プメンバーの方々には, 両地域の調査に際して様々 な情報を提供していただいた。記して感謝する。

\section{II. 調查の概要}

今回, 東京地学協会加ら研究 ·調査助成金を 得て, 1998 年 8 月と 9 月/10月にそれぞれ約 3 週 間と 2 週間，ロシア卓状地のモスクワ盆地および ドネッ炭田地域において野外調査を行なった。調 査においては, 石灰岩層を中心に, モスクワ盆地 周辺のセクションでは約 30 層準からの, またド ネッ炭田地域では約 50 層準からサンプルを採集 した。

モスクワ盆地周辺における調查では，同地域が 上部石炭系 Moscovian, Kasimovian, Gzhelian の模式地であることから，これら各層序ユニット の模式地を含む Podol'sk 採石場七クション（上 部 Moscovian 下部の Podolskian 模式地, Podolskian〜下部 Myachkovian), Domodedovo 採石場 セクション（上部Podolskian〜下部 Kasimovian), Gzhel セクション (Gzhelian 模式地), Konyashino 採石場七クション (下部 Gzhelian), Rusavkino 採石場七クション（下部 Gzhelian）, Afanasievo 採石場七クション (Myachkovian 下部 Kasimovian)，Peski 採石場セクション （Myachkovian 模式地）において調査を行なった (図 2)。

ドネッ炭田地域においては, ルガンスク市近郊 の Malomikolaivka セクション (Limestone $\mathrm{I}_{2} \sim \mathrm{K}_{3}=$ 上部 Bashkirian Moscovian 基底）と ペルボマイスク市近郊の Kalinovo セクション (Limestone $\mathrm{N}_{2} \sim \mathrm{P}_{5}=$ 最上部 Moscovian Gzhelian）において調査を行なった（図 3)。筆者 らは、これまでルガンスク市近郊の Karaguz 七 クション (Limestone $\mathrm{K}_{2} \sim \mathrm{L}_{7}=$ 下部 Moscovian) およびペルボマイスク市近郊の Gurkova セクショ ン (Limestone $\mathrm{M}_{1} \sim \mathrm{N}_{1}$ =上部 Moscovian) にお いても調査を行なっている。今回の調査により, 


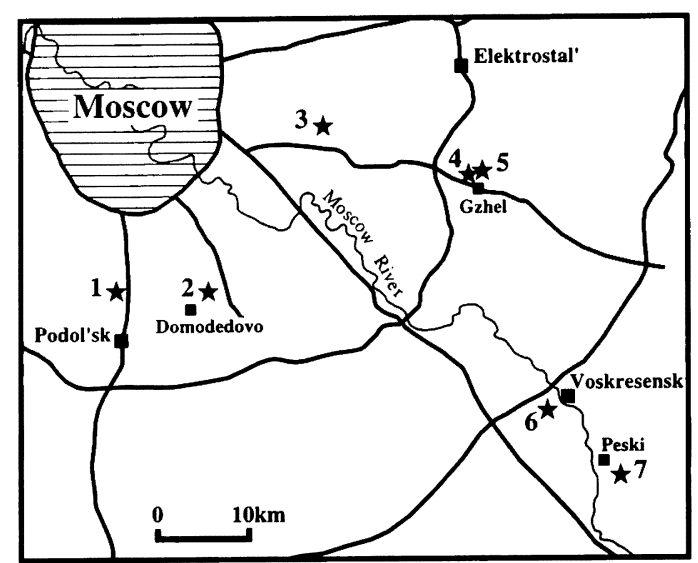

図 2 モスクワ盆地周辺における調査地点.

Fig. 2 Map showing the sections studied in the Moscow Basin, Russia.

Star mark means the section studied herein.

1. Podol'sk Quarry section, 2. Domodedovo Quarry section, 3. Rusavkino Quarry section, 4. Gzhel section, 5. Konyashino Quarry section, 6. Afanasievo Quarry section, 7. Peski Quarry section.

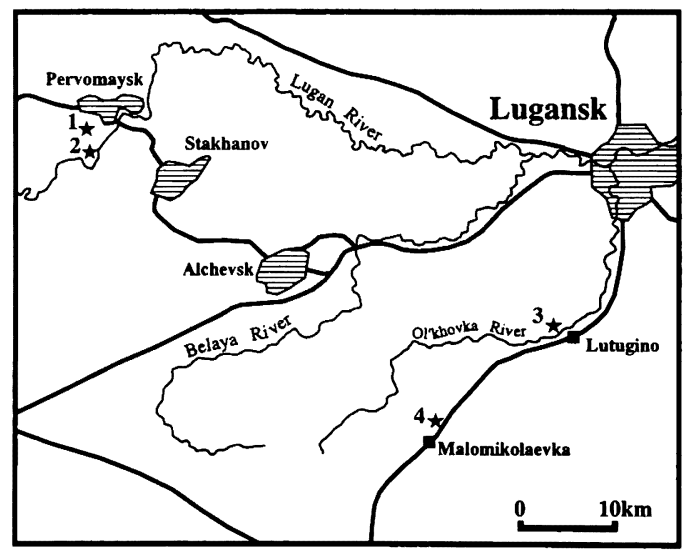

図 3 ウクライナ・ドネッ炭田地域における調査地点.

Fig. 3 Map showing the sections examined in the Donets Basin near Lugansk, Ukraine.

Star mark means the section studied herein.

1. Gurkova section, 2. Kalinovo section, 3. Karaguz section, 4. Malomikolaivka section.
ドネッ炭田地域の上部 Bashkirian から Gzhelian にかけてのほほ連続した層序を検討することがで きた。

III. ドネツ炭田地域, Kalinovo セクション における Moscovian/Kasimovian 境界 前後のフズリナ・コノドント群集変遷

ドネッ炭田地域東部, ルガンスク郡ペルボマイ スク市南方の Kalinovo 集落周辺には, 上部 Moscovianから Gzhelianにかけての地層が比較 的単純な地質構造のもと,ほぼ連続的に分布して いる。この地域は, 地形的には Lugan 川左岸の 緩やかな丘陵地帯で，その中に多くの小谷（ガリー） が刻まれている。地層の露出の多くはこのような 小谷内に限られるが, 石灰岩や粗粒砕屑岩類（砂 岩やレキ岩）などはやや侵食に強いため，緩やか な高まりを形成して連続良く露出していることが 多い。それに対して, 細粒砕屑岩類の露出は非常 に悪い。Kalinovo セクションに露出する石炭系 はほほ東西方向の走向を持ち, 南に $60^{\circ} \sim 70^{\circ}$ 傾斜 している。

Kalinovo セクションの層序に関しては, 1975 年にモスクワで開催された第 8 回国際石炭紀会議 におけるドネッ地域巡検ガイドブック (Aizenverg et al., 1975) に詳しく記載されてお り，その中で産出する化石群集の概要も簡単にで はあるが記されている。しかしながら，ガイドブッ クという性格上詳しい有孔虫（特にフズリナ）生 層序については議論されておらず, 標本の図示も なされていない。また,コノドントに関しては, Kozitskaya et al. (1978) のモノグラフの他, Heckel et al. (1998) によるコノドント生層序の 概要報告がごく最近なされたにすぎない。このセ クションはドネツ炭田地域に掞ける上部石炭系の 最も重要な連続セクションであるにもかかわらず， その有孔虫・コノドント生層序に関してはいまだ 十分な報告がない現状にある。Kalinovoセクショ ンには最上部 Moscovian (Limestone $\mathrm{N}_{2}$ ) から Gzhelian (Limestone $\mathrm{P}_{5}$ ) までの露出があるが, 今回はこれまでに比較的詳しいデータが得られて いるセクション下部 (Limestone $\mathrm{N}_{2} \sim \mathrm{O}_{4}$ ) のフ 


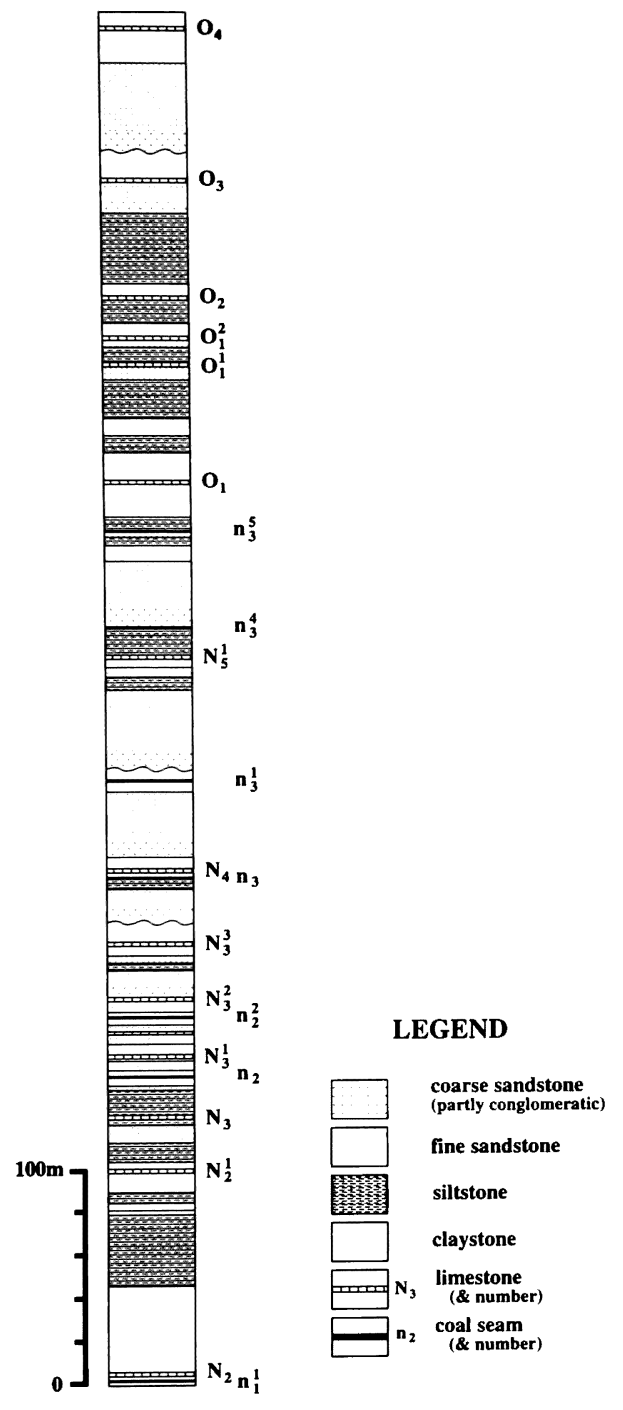

図 4 Kalinovoセクション下部の柱状図.

Fig. 4 Columnar section of the lower part of the Kalinovo section, about $5 \mathrm{~km}$ south of Pervomaysk in the Lugansk County, Ukraine. (slightly modified from Aizenverg et al., 1975)

\section{ズリナ・コノドント群集変遷について述べる。}

図 4 にKalinovo セクション下部の柱状図を示 す。ドネッ炭田地域の石灰岩層には, 例えば $\mathrm{O}_{1}$ のように，慣例的に大文字のアルファベットと数 字からなる記号が下位より順に付けられている。
同様に，石炭層に対しては小文字のアルファベッ トが使われている。調査では, $\mathrm{N}_{2}, \mathrm{~N}_{3}, \mathrm{~N}_{3}{ }^{1}, \mathrm{~N}_{3}{ }^{2}$, $\mathrm{N}_{3}{ }^{3}, \mathrm{~N}_{5}{ }^{1}, \mathrm{O}_{1}, \mathrm{O}_{1}{ }^{1}, \mathrm{O}_{1}{ }^{2}, \mathrm{O}_{2}, \mathrm{O}_{3}, \mathrm{O}_{4}$ の 12 石灰 岩からサンプルを採集し, 含まれる有孔虫・コノ ドント類を検討した。今回の調査では, Aizenverg et al.(1975) が Kalinovo セクション において露出を記述している $\mathrm{N}_{2}{ }^{1}$ と $\mathrm{N}_{4}$ について は確認できなかった。

$\mathrm{N}_{2}$ はウミユリ片を多く含む暗灰色の塊状石灰 岩で, 恐らくQuasifusulinoides（あるいは進化 型のFusulina）と思われるフズリナとともに，大 型の Taitzehoella, Ozawainella, Schubertella, Eostaffella が産出する。またコノドント類は, Gondolella elegantula, G. laevis, Idiognathodus robustusなどの他, Neognathodus inaequalis が産出する。

$\mathrm{N}_{3}$ は厚さ約 $1 \mathrm{~m}$ で，基底部はやや砂質，下部 は chaetetid boundstoneからなり，上部は泥質 な phylloid algal 石灰岩である。この石灰岩から はQuasifusulinoides, Schubertella, Eostaffella とともに, 産出量は少ないものの最初のProtriticitesの産出が確認された。一方，コノドント類 は Idiognathodus robustus 1 個体のみの産出で あった。

その上位の $\mathrm{N}_{3}{ }^{1}, \mathrm{~N}_{3}{ }^{2}, \mathrm{~N}_{3}{ }^{3}$ はいずれも泥質な薄 い石灰岩で, 有孔虫類およびコノドント類の産出 は少ない。コノドント類は $\mathrm{N}_{3}{ }^{2}$ と $\mathrm{N}_{3}{ }^{3}$ から Streptognathodus subexcelsus が産出するが，有 孔虫類は $\mathrm{N}_{3}{ }^{3}$ からのみ Ozawainella ex gr. angulata や Fusiella ex gr. typica, Eostaffella sp. などが産出するのが確認された。さらに上位 の $\mathrm{N}_{5}{ }^{1}$ は 3 枚の非常に泥質な石灰岩層から構成さ れており，フズリナ類の産出は確認されなかった が, Streptognathodus subexcelsus のほか， Idiognathodus 属のコノドントが多産した。

一方, 次の $\mathrm{O}_{1}$ は厚さ $3.5 \mathrm{~m}$ の連続性の良い成 層した灰白色石灰岩層で, Lugan 川沿いの道路脇 に全体が観察できる小露頭がある。この石灰岩か らはObsoletes が多産し、Quasifusulinoides や 大型の Fusiella ( $F$. lancetiformis あるいは $F$. lawiに似る), Ozawainella, Schubertella, 
Eostaffella，そして個体数は少ないものの Protriticites と思われるフズリナ類も産する。コ ノドント類はStreptognathodus oppletus の他, 産出は少ないものの Gondolella sublanceolata が確認された。

$\mathrm{O}_{1}{ }^{1}$ と $\mathrm{O}_{1}{ }^{2}$ はいずれも薄い不純な石灰岩層で, フズリナ類の産出は見られないが, コノドント類 はIdiognathodus sagittalis が $\mathrm{O}_{1}{ }^{2}$ から多産した。 その上位の $\mathrm{O}_{2}$ は厚さ約 $1.3 \mathrm{~m}$ の灰白色石灰岩層 で， $\mathrm{O}_{1}$ 同様連続性が良い。下部はやや nodular であるが上部ではウミユリ片を主体とする wackestone/packstone となる。この石灰岩からは,

Montiparus umbonoplicatusに類似するMontiparus が多産し，その他にQuasifusulinoides や Ozawainella, 大型の初室を持った Eostaffella 等が産する。コノドントは Gondolella sublanceolata, Gondolella magna, Streptognathodus cancellosus の産出が確認された。

$\mathrm{O}_{3}$ 石灰岩は $\mathrm{O}_{2}$ の上位約 $50 \mathrm{~m}$ に露出する, ウ ミュリ, フズリナを多量に含む層厚 $70 \mathrm{~cm}$ の石灰 岩で、Quasifusulina が多産する。随伴するフズ リナ類としては, Schubertella, Fusiella, そし て $\mathrm{O}_{2}$ から産するのと同様な大型の初室を持った Eostaffella が認められた。さらに上位の $\mathrm{O}_{4}$ は厚 さ $1.2 \mathrm{~m}$ の成層した石灰岩で, phylloid algaeが 多産するがフズリナ類は見られない。 $\mathrm{O}_{3}$ および $\mathrm{O}_{4}$ 両石灰岩からは, 今回コノドントの産出は確 認できなかった。

これらフズリナ群集の中で, $\mathrm{N}_{3}$ からの群集は 最初の確実なProtriticites を含むものであり, 随 伴するフズリ十類も合わせて考えると最上部 Moscovian（モスクワ盆地の上部 Peski 層）に対 比可能である。一方，それより上位でフズリナに よって年代対比の議論が行える最も下位の層準は $\mathrm{O}_{1}$ である。 $\mathrm{O}_{1}$ からは Obsoletes が産出しており, 年代的には Kasimovian 前期と考えられる。 $\mathrm{N}_{3}$ と $\mathrm{O}_{1}$ の間は石灰岩層の露出状況が悪く, また石 灰岩の多くがフズリナ類の産出にはあまり好まし くない泥質あるいは砂質の不純な石灰岩である。 このように,フズリナ群集の検討からは Moscovian/Kasimovian 境界が $\mathrm{N}_{3}$ と $\mathrm{O}_{1}$ 石灰岩の間の
層準に存在することは明らかであるが, 現在のと ころ詳細な境界層準の決定には至っていない。

一方コノドント類は, 後期 Moscovian の代表 種である Neognathodus inaequalis が $\mathrm{N}_{2}$ まで産 出するが, それより上位からの産出は今回確認さ れなかった。また, Kasimovian 最下部から産出 が始まるとされる Streptognathodus subexcelsus が $\mathrm{N}_{3}{ }^{2}$ から確認されたのをはじめ,これより上位 からは前期 Kasimovianの代表種である Idiognathodus sagittalis や Gondolella sublanceolata, Gondolella magnaなどの産出が確認さ れた。以上今回のコノドント群集の検討から， Moscovian/Kasimovian 境界は $\mathrm{N}_{3}{ }^{2}$ 石灰岩付近 に置くのが妥当であると考えられる。なお, 最近 Heckel et al. (1998)もコノドント類の検討から, ドネッ炭田地域の Moscovian/Kasimovian 境界 を $\mathrm{N}_{3}^{2}$ の下位に置いている。

\section{IV. まとめと今後の課題}

今回の調查において，モスクワ盆地では上部 Moscovianから下部 Gzhelianにかけて，またド ネッ炭田地域では最上部 Bashkirianから Gzhelian 上部にかけての層準において調査を行な うことができ, 調査した層準よりほぼ連続的に有 孔虫・コノドント群集変遷を検討するためのサン プルを採集することができた。 現在, サンプル の処理と有孔虫・コノドント群集の詳しい検討を 順次進めている段階であるが, ドネッ炭田地域の Kalinovo セクションにおける Moscovian / Kasimovian 境界前後のフズリナ・コノドント群 集変遷に関しては，上に報告したような詳細なデー タが集まりつつある。

このように現状ではいまだ予察的な段階ではあ るが, 今後サンプル処理を進めることによってこ れまで以上に精度の高い年代対比が議論可能であ ると考えられ, その意味においてもロシア卓状地 における対比解像度の高い有孔虫・コノドント複 合生層序確立の糸口がつかめたと言える。 


\section{文献}

Aizenverg, D.E., Babenko, A.M., Belenko, N.G., Belokon, V.G., Bragin, Yu.N., Dedov, V.S., Fissunenko, O.P., Getman, V.G., Konashov, V.G., Lagutina, V.V., Levenshtein, M.L., Makarov, I.A., Nagorny, Yu.N., Nesterenko, L.P., Poletaev, V.I., Popov, V.S., Rotai, P.P., Sharmanova, G.V., Shchegolev, A.K. and Sokolova, G.U. (1975): Field excursion guidebook for the Donets Basin (VIII International Congress on Carboniferous stratigraphy and Geology, Moscow). Izdatel. Nauka, Moskow, 360p. (in Russian and English)

Einor, O.L. (1996): The former USSR. In Wagner, R.H., Winkler Prins, C.F. and Granados, L.F. eds.: The Carboniferous of the World III, The former USSR, Mongolia, Middle Eastern Platform, Afghanistan, \& Iran. IUGS Publication, 33, Instituto
Tecnologico, GeoMinero de Espana, Madrid and Nationaal Natuurhistorisch Museum, Leiden, 13-407.

Heckel, P.H., Alekseev, A.S. and Nemirovskaya, T.I. (1998): Preliminary conodont correlations of late Middle to early Upper Pennsylvanian rocks between North America and Eastern Europe. Newsletter on Carboniferous Stratigraphy, 16, 8-12.

Kozitskaya, R.I., Kosenko, Z.A., Lipnyagov, O.M. and Nemirovskaya, T.I. (1978): Konodonty karbona Donetskogo basseyna. Izdat. Naukova Dumka, Kiev, 134p. (in Russian)

Wagner, R.H. and Higgins, A.C. (1979): The Carboniferous of the USSR; Its stratigraphic significance and outstanding problems of world-wide correlation. In Wagner, R.H., Higgins, A.C. and Meyen, S.V. eds.: The Carboniferous of the U.S.S.R. Yorkshire Geol. Soc., Occasional Publication, 4, 5-22. 